\title{
PEMS-based investigations into exhaust emissions from non-road and rail vehicles
}

\begin{abstract}
At the beginning of the twenty-first century, one of the major challenges of humanity was to reduce the negative effects of civilization development. Besides the engines used in road vehicles there is a large group of engines for non-road applications. This group includes motor propelled vehicles not used on the road NRMM (Non-Road Mobile Machinery). Engines of these vehicles, among all of the non-road applications, are characterized by very specific working conditions that do not allow for them to be qualified for propulsion engines. The main problem with these vehicles is the particulate matter and nitrogen oxides emission. Rail vehicles operating conditions these requirements take by the similar way, as having a wide range of rolling stock markedly alters the environmental impact of these vehicles. Thus it becomes necessary to consider the issue of the method of evaluation of engine emissions in rail vehicles in terms of their actual operating conditions. Thus, efforts to assess the actual level of emissivity for rail vehicles and attempts to improve it are necessary and justified.
\end{abstract}

Key words: non-road vehicle, rail vehicles, pollution emissions, real driving emissions, portable emissions measurement systems

\section{Introduction}

\subsection{General characteristic of non-road engines}

Engines of non-road applications constitute a wide group that includes engines of: handheld portable devices (lawnmowers, chainsaws), power generators and non-road vehicles (otherwise referred to as NRMM - Non-Road Mobile Machinery). The NRMM vehicle group includes construction machinery, farm tractors and machines as well as special purpose machinery. The NRMM engines are a vast group among the non-road engine group (Fig. 1). The engines of these vehicles are characterized with very specific operating conditions, which is why they cannot be classified as traction engines.

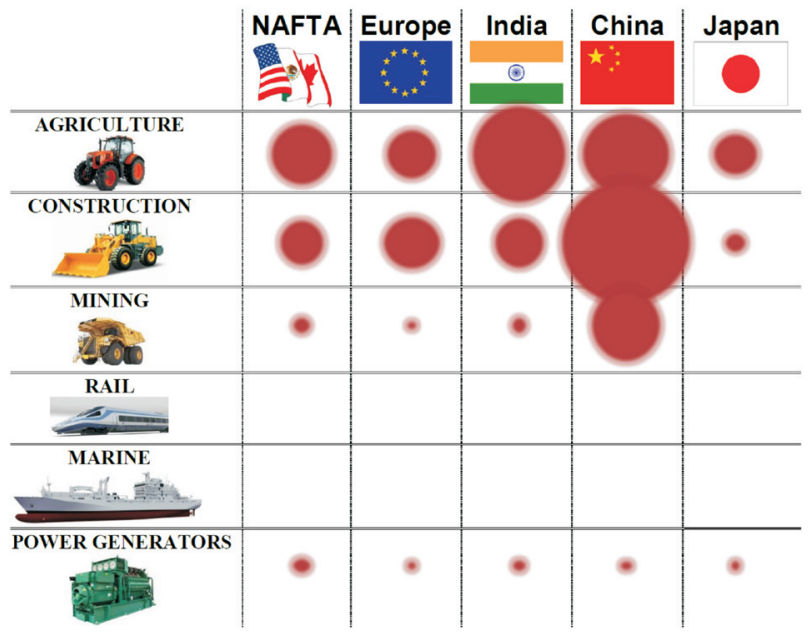

Fig. 1. The share of non-road engines in selected regions of the world [3]

A recent increase in the sales of NRMM vehicles has been greater than that of heavy-duty vehicles (HDV) (Fig. 2) [1]. The advancement of the transport infrastructure and the development of cities result in a continuous increase in the sales of construction machinery worldwide. A similar situation is observed in the farm tractor and machine market. The advancement and modernization of the farms resulted in an increased number of farm vehicles and machinery. A good example is Europe, where the number of operated farm tractors grew significantly in past decades [16]. A great influence on the number of NRMM vehicles have the emerging markets such as China, India and Eastern Europe. It is forecasted that this trend will continue in the coming years.

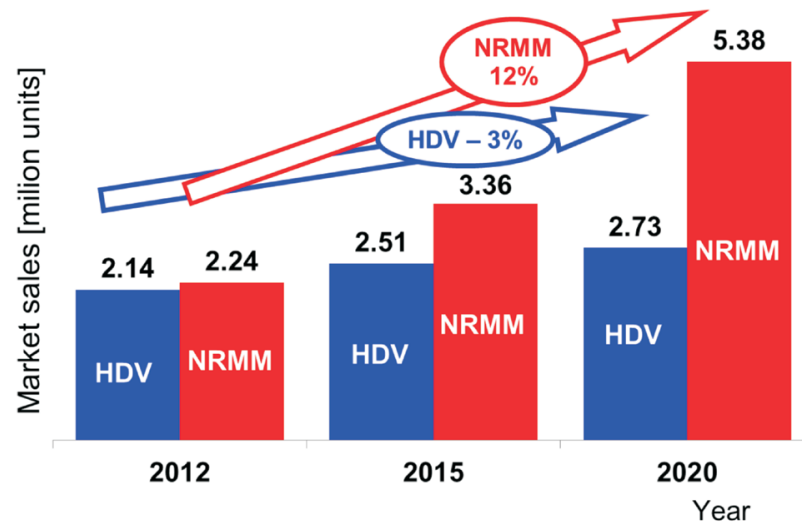

Fig. 2. Sales of HDV and NRMM vehicles (2020 - forecasted) [2]

The main problem in relation to the NRMM vehicles is the emission of particulate matter (PM) and nitrogen oxides $\left(\mathrm{NO}_{\mathrm{x}}\right)$. The scale of the problem is well depicted by the situation in Germany, where the share of PM in the exhaust emissions from engines of non-road applications has for years been maintained on a steady level of approx. 50\% (Fig. 3 ) [4]. The share of the emission of $\mathrm{NO}_{x}$ from the engines of non-road applications in Germany is lower compared to that of PM and amounts to approx. $15 \%$, which is still a high value (Fig. 4). When it comes to the application of diesel engines constituting the main powertrain of NRMM 
vehicles, their impact on human health and environment is quite important. In its report published in 2012, International Agency for Research of Cancer (IARC), one of the agencies of World Health Organization (WHO) informed that diesel exhaust gas is carcinogenic [5]. Because of the number of diesel engines, the potential related to the reduction of exhaust emissions from this group of vehicles is the main research goal of this work.

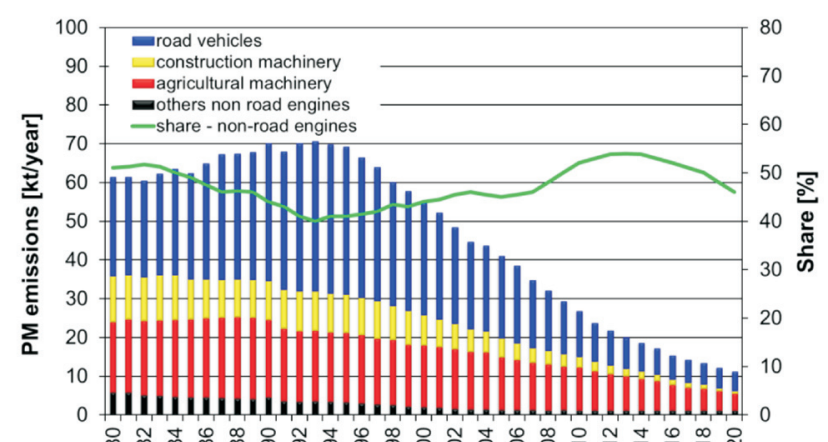

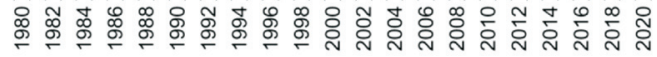

Year

Fig. 3. Emission of PM from the engines operated in Germany (2014-2020 - forecast) [4]

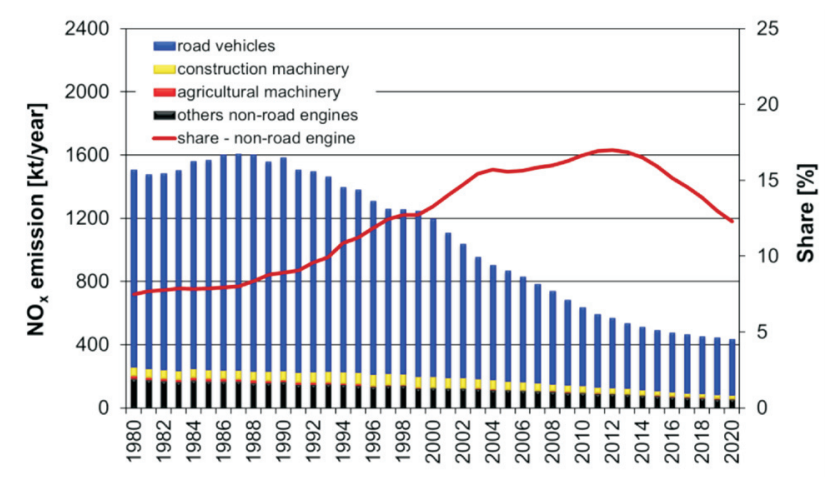

Year

Fig. 4. Emission of $\mathrm{NO}_{\mathrm{x}}$ from the engines operated in Germany (2014-2020 - forecast) [4]

\subsection{General characteristics of rail vehicles}

Diesel direct injection rail vehicles traction engines still remain the main powertrain solution for these vehicles because of their unique advantages. Yet, the negative impact of these engines on the natural environment is significant (Fig. 5). In Poland there are many traction vehicles whose engines do not meet the exhaust emissions requirements.

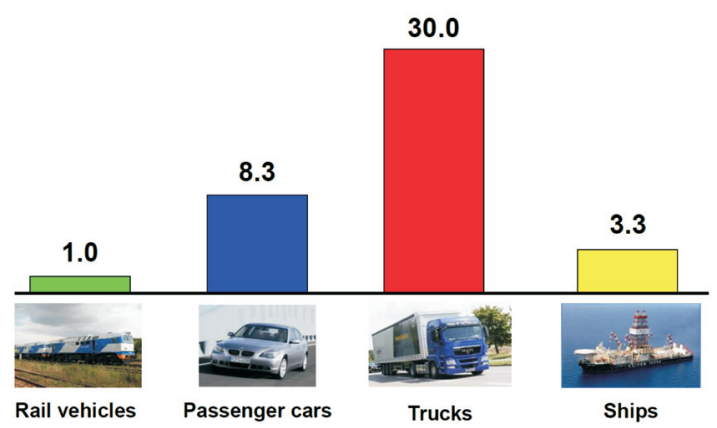

Fig. 5. Relative environment burden by the above means of transportation [22]
The influence of the locomotives on the natural environment depends on the characters of their operation. It is the locomotive operating conditions that decide about its unit fuel consumption, hence the exhaust emissions. The share of operation of a shunting locomotive at idle amounts to $51.6 \%$ of the total operating time, $33 \%$ of that time corresponds to $10 \%$ of the rated usable power and the outstanding shares are miniscule [21].

The ecological evaluation of diesel powertrains is extremely disadvantageous as compared to electric powertrains (Fig. 6). The damage done to the environment by the diesel traction vehicles in Poland when transporting cargo is four times higher than in the case of electric traction vehicles and 1.8 times higher that it is in the case of river transport but is 5 times lower than the damage done to the environment by heavy duty diesel vehicles. The exhaust emissions from non-road vehicles (rail vehicles also belong to that category) constitute a significant share in relation to the road vehicles [7-9].

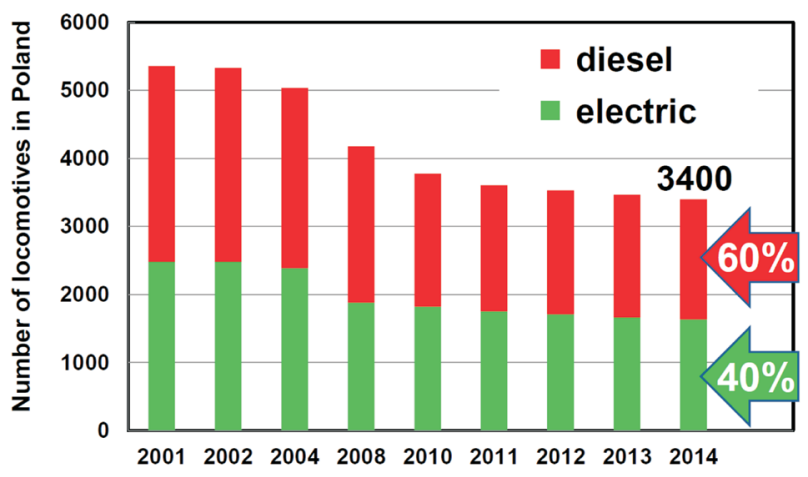

Fig. 6. The shares of diesel and electric locomotives in the rail rolling stock in individual countries

The study discusses the issues related to the ecological operation of rail vehicles. The evaluation of the level of environment friendliness is in most cases based on the comparison of the emission level of a traction combustion engine with the applicable exhaust emission limits. These values pertain to research tests of engines and vehicles. Under local (country) conditions of rail vehicles operation these requirements look a bit different because having a wide variety of rolling stock significantly changes the status of this kind of transportation in terms of environment friendliness. It is thus necessary to decide about the methodology of the evaluation of the rail vehicles emission level under real operating conditions. Hence, any actions aiming at the evaluation of the emission level of rail vehicles under real operating conditions are necessary and fully justified.

\section{Potential of PEMS measurement}

Aside from measurements performed on motor vehicles (including off-road) the system allows coordinating the exhaust emissions measurements from heavy-duty trucks, buses (including hybrid), construction and farm machinery (non-road), rail vehicles, ships and aircraft fitted with piston and jet engines (Fig. 7). 
1. Gaseous exhaust emissions (CO, HC, NOx)

- Semtech DS (Sensors)

- Ecostar (Sensors)

- M.O.V.E. (AVL)

2. Particle mass (PM) \& number (PN) emissions

- Micro Soot Sensor (AVL)

- Ecostar PM (Sensors)

- Particle Counter (AVL)

- Ecostar PN (Sensors)

- EEPS (TSI) - Particle size distibution
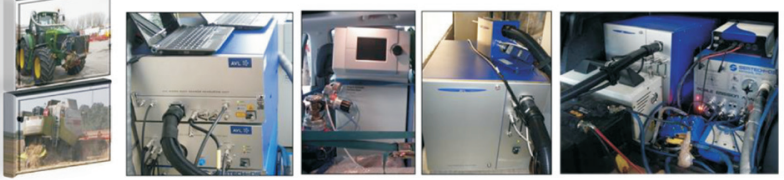

Fig. 7. Example applications of the PEMS equipment (PEMS components listed)

As for other applications of combustion engines in motor vehicles of the GVW exceeding $3500 \mathrm{~kg}$ (heavy-duty trucks and buses), off-road vehicles, construction and farm machinery (non-road), rail vehicles, ship and aircraft fitted with piston and jet engines - the engines are removed and tested on engine dynamometers [17, 18]. These engines operate under artificial conditions, usually much different than the actual ones. For the assessment of exhaust emissions after a certain period of operation the engine would have to be removed from the vehicle, which is technically and economically infeasible. The proposal to test vehicles using portable exhaust emissions measurement systems is a universal solution as it can be used in vehicles of all applications, where the same engines are applied.

A solution to this problem is the use of portable exhaust emissions measurement systems (PEMS). The system is composed of $\mathrm{CO}, \mathrm{CO}_{2}, \mathrm{HC}, \mathrm{NO}_{\mathrm{x}}$ and particulate matter measuring devices (equipment measuring particulate matter measures its mass, number and diameter). The system also acquires engine and vehicle operating parameters from the on-board computer (via CAN-bus).

The authors of the paper propose an introduction of an exhaust emissions conformity factor (CF) denoting the multiple of the increase or decrease of the exhaust emissions under actual traffic conditions compared to the homologation tests. Such an index has been defined for a given exhaust component (CF - exhaust emission conformity factor) [13]:

$$
\mathrm{CF}_{\mathrm{j}}=\frac{\mathrm{E}_{\text {real }, \mathrm{j}}}{\mathrm{E}_{(\mathrm{WHTC}), \mathrm{j}}}
$$

where: $\mathrm{j}$ - exhaust component for which the emission index was determined, $\mathrm{E}_{\text {real,j }}$ - emission under actual traffic conditions $[\mathrm{g} / \mathrm{kWh}], \mathrm{E}_{\mathrm{WHTC}, \mathrm{j}}$ - emission measured in the WHTC test $[\mathrm{g} / \mathrm{kWh}$ (for heavy-duty vehicles).

The proposed exhaust emissions conformity factor will adapt the homologation emission values obtained in the tests to the actual traffic conditions of a vehicle. Hence, the conformity factor, referred to as ' $\mathrm{CF}$ ', should be dimensionless and determined for different emission categories:
- passenger and light-duty trucks (up to $3500 \mathrm{~kg}$ ) - for which the emission limits are prescribed in grams per kilometer $[\mathrm{g} / \mathrm{km}]$,

- heavy-duty and non-road vehicles - for which the emission limits are prescribed in grams per kilowatt hour $[\mathrm{g} / \mathrm{kWh}]$.

\section{Exhaust emission form non-road vehicles in real operating conditions}

\subsection{NRMM real operating conditions and emissions}

PEMS-based investigations under actual operating conditions allow determining the exhaust emissions and engine operating parameters such as engine load and speed in particular. Analyses of the conditions of actual operation of non-road engines confirm that most of them are specific and distinct compared to road vehicle engines $[6,12]$. An example could be the engine of a farm tractor that operates under load characteristics during fieldwork, i.e. a constant operating speed varies in a narrow range, which mainly results from instantaneous and sudden load changes (Fig. 8). Figure 9 presents the view of the tractor during the tests with the hourly emission of $\mathrm{NO}_{\mathrm{x}}$ shown on the tractor route. From this course, it clearly results that the emission remains on a steady level, except for instantaneous surges resulting from an increased load and while making U-turns, when the engine load and its speed change. Such a course of engine parameters is characteristic of a numerous group of NRMM vehicles [6].

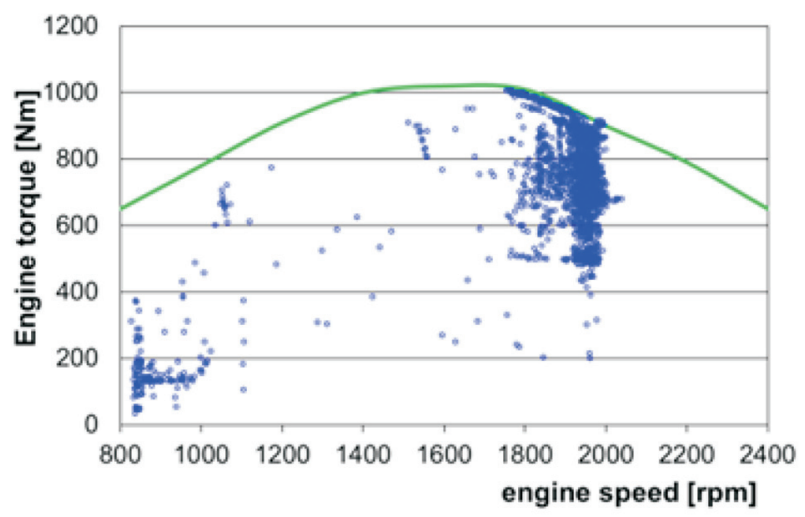

Fig. 8. Farm tractor engine parameters under actual operation (ploughing)

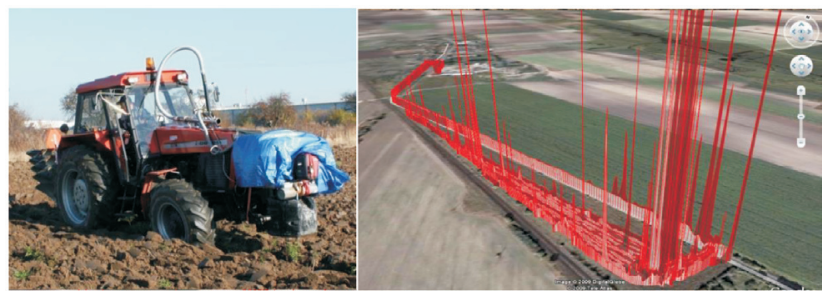

Fig. 9. Farm tractor during the tests under actual conditions of operation and the emission of $\mathrm{NO}_{\mathrm{x}}$ shown on the tractor route

The performed tests for a large group of farm, forest and construction machines confirm that the main problem during the operation under actual conditions is the emission of PM and $\mathrm{NO}_{\mathrm{x}}$ [11]. The legislation related to the NRMM 
exhaust emissions testing procedures has not yet been fully developed and established, but the European proposal of the future limits provides a $\mathrm{CF}$ for all exhaust components of 1.5. The CF obtained according to relation 1 confirms that for almost all tested vehicles the $\mathrm{CF}$ is greater than the proposed limit (Fig. 10). The forest harvester is an exception here, in which case the $\mathrm{CF}$ for both $\mathrm{PM}$ and $\mathrm{NO}_{\mathrm{x}}$ is below the proposed limits. It is noteworthy that the $\mathrm{CF}$ for $\mathrm{CO}$ and $\mathrm{HC}$ for all tested vehicles is below the proposed CF limit.

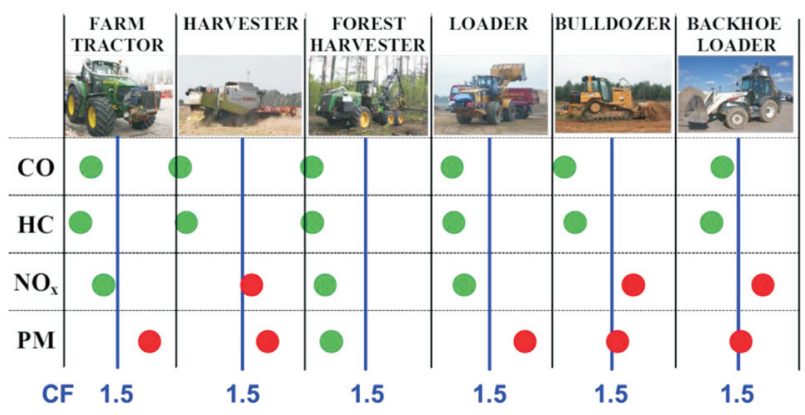

Fig. 10. CF for the investigated NRMM vehicles

\subsection{Emissions standards for NRMM}

One of the main goals of the EU directives was to set the admissible exhaust emission limits. Throughout the years, they became increasingly stringent. Despite the fact that the HDV and NRMM engines have similar characteristics and power outputs, the admissible limits for the NRMM are less stringent. A comparison of the admissible emission limits of $\mathrm{PM}$ and $\mathrm{NO}_{\mathrm{x}}$ in the European legislation for the HDV and NRMM engines have been shown in Figures 11 and 12. The comparison pertains to the engines of the power output of $130-560 \mathrm{~kW}$; this is a range of power output typical of heavy-duty diesel engines (HDD).

In the future, one should expect further tightening of the emission and fuel consumption (emission of $\mathrm{CO}_{2}$ ) limits related to the NRMM engines [15]. This will ensure a modernization of the design of engines as well as the entire powertrains. The research and development centers are already working on such solutions. Intense works are under way on hybridization and electrification of NRMM powertrains $[14,19,20]$.

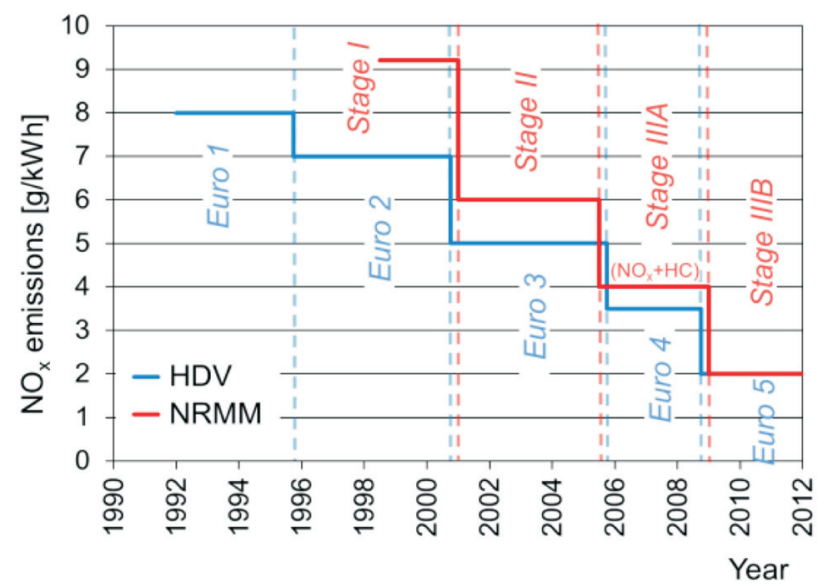

Fig. 11. Comparison of the admissible values of the $\mathrm{NO}_{x}$ emission for the HDV and NRMM engines (130-560 kW) [25]

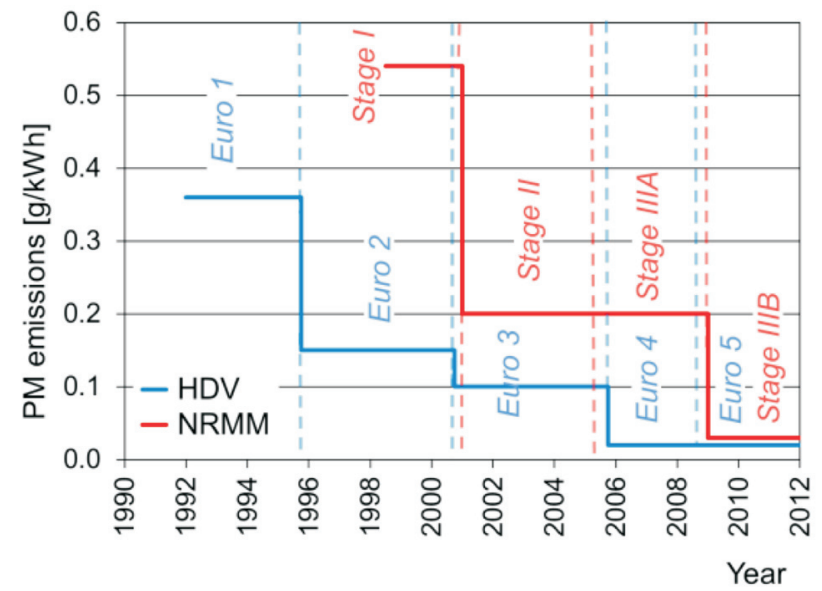

Fig. 12. Comparison of the admissible values of the PM emission for the HDV and NRMM engines (130-560 kW) [25]

A homologation stationary test for non-road engine applications is a NRSC (Non-Road Stationary Cycle) test [25]. This is an 11-phase test performed on an engine test bed. On its basis, the average emissions of individual exhaust components are determined. The characteristic share coefficients in each test phase are selected depending on the tested engine [25]. For the NRMM vehicles, the stationary test is ISO 8178-C1. Ever since the introduction of the Stage III emission limit, the exhaust emission measurements on NRMM vehicles have also been carried out in a dynamic NRTC (NonRoad Transient Cycle) test. The ISO 8178 test was renamed to NRSC (Non-Road Stationary Cycle). The NRTC test was developed jointly by the European and American legislators. For the tested engine, the NRTC is performed twice: for a cold and warm engine start. The final result is a weighted average with a share coefficient of 0.1 for the cold start test (in the US - 0.05) [25].

\section{Exhaust emission from rail vehicles in real operating conditions}

\subsection{Diesel locomotives in passenger and cargo} transportation in Poland and in the world

A characteristic feature of locomotives for passenger transportation is that they are designed to operate as slow and fast trains. They have a source of power for central heating of the train under low ambient temperatures (heating boilers, heat generators). The locomotives for passenger trains also have specific traction characteristics, particularly in terms of their operating speed. Cargo lugging locomotives do not have a heating system for the train cars and their traction characteristics should be described as high loads at low speeds. Universal locomotives have both characteristics of those designed for lugging cargo and passenger trains.

Shunting locomotives are designed to lug or push rail cars on the tracks, sidetracks and marshalling yards. We can also distinguish industrial locomotives that are practically shunting locomotives but some of them operate under specific conditions e.g. extreme air pollution (steelworks, coal grading sites, mines) and elevated temperatures (steelworks when transporting the products of the metallurgical process). 
When it comes to the type of applied transmission of torque from the engine to the wheels (including its adjustment) we can distinguish locomotives fitted with mechanical hydraulic, (hydrostatic, hydrodynamic) and electric (direct current, alternating current) transmissions.

A significant share of this type of vehicles in the rolling stock certainly results from the advantages that this means of transport provides. Diesel locomotives have the following advantageous features as opposed to electric locomotives:

- Power supply independent from external sources, which is vital in case of natural disasters. Under such exceptional situations diesel locomotives can fully stand in for the electric ones,

- The possibility of implementing: innovative solutions in the powertrains of diesel locomotives, various types of energy conversion and electric transmissions,

- Diesel locomotives can operate under severe ambient conditions, which can be a serious problem for the electric locomotives,

- Diesel locomotives have a higher efficiency $\left(\eta_{\mathrm{o}}=0.26\right)$ as compared to the electric locomotives $\left(\eta_{0}=0.21\right)$.

Polish Rail currently uses 12 series of regular gauge diesel locomotives of power outputs from $110 \mathrm{~kW}$ to 900 kW (Fig. 13 and Table 1). Each year the number of diesel locomotives gets reduced both in Poland and the EU member states because they are gradually being replaced by the electric locomotives (lower costs of operation on lines of higher train traffic) $[9,23]$.

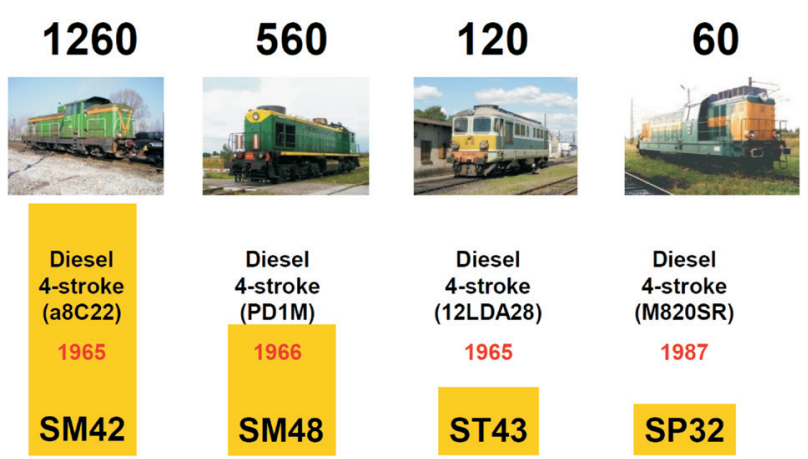

Fig. 13. Diesel locomotives in Poland

Table 1. Shunting locomotives operated in Poland [24]

\begin{tabular}{|c|c|c|c|c|c|}
\hline No. & Series & $\begin{array}{c}\text { Country of } \\
\text { production }\end{array}$ & $\begin{array}{c}\text { Engine type/ } \\
\text { power }[\mathrm{kW}]\end{array}$ & $\begin{array}{c}\text { Service } \\
\text { weight } \\
{[\mathrm{Mg}]}\end{array}$ & $\begin{array}{c}\text { Maximum } \\
\text { traction } \\
{[\mathrm{MN}]}\end{array}$ \\
\hline 1. & SM03 & Poland & $\begin{array}{c}\text { Diesel, } \\
\text { 4-stroke/110 }\end{array}$ & 24 & 58.5 \\
\hline 2. & SM30 & Poland & $\begin{array}{c}\text { Diesel, } \\
\text { 4-stroke/257 }\end{array}$ & 36 & 75 \\
\hline 3. & SM31 & Poland & $\begin{array}{c}\text { Diesel, } \\
\text { 4-stroke/883 }\end{array}$ & 116 & 220 \\
\hline 4. & SM40 & Hungary & $\begin{array}{c}\text { Diesel, } \\
\text { 4-stroke/441 } \\
\text { Diesel, } \\
\text { 4-stroke/441 }\end{array}$ & 62 & 182.6 \\
\hline 5. & SM41 & Hungary & $\begin{array}{c}\text { Diesel, } \\
\text { 4-stroke/588 }\end{array}$ & 70 & 228 \\
\hline 6. & SM42 & Poland & $\begin{array}{c}\text { Diesel, } \\
\text { 4-stroke/883 }\end{array}$ & 116 & 380 \\
\hline 7. & SM48 & USSR & & & 182.6 \\
\hline
\end{tabular}

Until 2020 in Europe the number of diesel locomotives will drop but the number of diesel multiple units for local passenger transportation tasks will grow. The UIC analyses indicate that by 2020 the companies plan to purchase approximately 9000 new locomotives and 8500 diesel multiple units.

The development of the locomotives with respect to the fuels for their powertrains is in line with the development trends in road and non-road transportation not to mention the air transportation. Their development will much depend on the development of new technologies in land and air transportation and will seek advanced technologies that will ensure the optimum use of the energy supplied to the vehicles maintaining high safety of the realized transportation task and low emission level. The trends in the development of locomotives will be characterized by attempts to:

- Use modern engines in new and currently operated locomotives,

- Increase usable power output at a steady fuel consumption,

- Reduce exhaust emissions and noise level,

- Reduce heat emission from the engine,

- Optimize the design of the engine aggregates in terms of fuel consumption and the costs of production,

- Develop diesel-electric locomotive powertrains,

- Develop electric powertrains with a new generation of batteries and electric motors,

- Apply biofuels for use in diesel and diesel electric locomotives operated under various transportation and industrial tasks.

A wide application of microchip technologies in vehicles indicates that also in the locomotives such a technology will find its application for the control of the engine operation, safety systems and on-board diagnostics of the locomotive in the long term (realized similarly to the OBD systems OnBoard Diagnostics) used in road vehicles.

\subsection{Emission standards}

European rail vehicles exhaust emission regulations are as follows: locomotives (including shunting locomotives) and railcars have been included in the UIC 624 charter. The admissible values of the emissions were established in 2001 and they are applicable to new railway vehicle engines. The applicable test is ISO 8178-F [18]. The regulations do not apply to special purpose locomotives (operated in refineries or mines) and traction engines of power output below 100 $\mathrm{kW}$. The UIC I limits were applicable for all the engines until 31.12.2002, and from 1.01.2003 onwards (UIC II) a division applies to engines of power output up to 560 $\mathrm{kW}$ and engines above that value. The exhaust gas components that undergo the measurement were also changed. Exhaust gas opacity test has been given up in favor of the measurement of the PM level (UIC II as is in the case of the Euro standards). It is noteworthy that from 2008 the UIC limits have been getting closer to the level IV of the Euro standard (Fig. 14). 


\begin{tabular}{|c|c|c|c|c|c|}
\hline $\begin{array}{l}\text { Emission } \\
\text { standard }\end{array}$ & $\begin{array}{l}\text { Valid } \\
\text { from }\end{array}$ & $\begin{array}{c}\mathrm{NO}_{\mathrm{x}} \\
{[\mathrm{g} / \mathrm{kWh}]}\end{array}$ & $\begin{array}{c}\mathrm{HC} \\
{[\mathrm{g} / \mathrm{kWh}]}\end{array}$ & $\begin{array}{c}\mathrm{Co} \\
{[\mathrm{g} / \mathrm{kWh}]}\end{array}$ & $\begin{array}{c}\text { PM } \\
{[\mathrm{g} / \mathrm{kWh}]}\end{array}$ \\
\hline Stage I & 2001 & 9.2 & 1.3 & 5.0 & 0.54 \\
\hline Stage II & 2002 & 6.0 & 1.0 & 3.5 & 0.2 \\
\hline Stage IIIA & 2006 & \multicolumn{2}{|c|}{4.0} & 3.5 & 0.2 \\
\hline Stage III B & 2010 & 2.0 & 0.19 & 3.5 & 0.025 \\
\hline Stage IV & 2013 & 0.4 & 0.19 & 3.5 & 0.025 \\
\hline
\end{tabular}

Fig. 14. Emission standards [25]

\subsection{Improving ecological parameters of rail vehicle diesel powertrains}

Engine adjustment

The locomotive engine rebuilds results in a partial reduction of the exhaust emissions: the obtained results meet (with a sizable margin) the ORE B13 as well as the UIC standards (the latter only for the unit emission of carbon monoxide). This allows the evaluation of the appropriate adjustment of the supercharging pressure or maintaining excessive values thereof (which can be implied by high $\mathrm{NO}_{\mathrm{x}}$ ). The growth in the emission of hydrocarbons may result from the fact that the engine is not yet properly run in, but the results significantly exceed the admissible UIC limits. The course of the injection was improved (injection advance angle) which is confirmed by a lower emission of nitrogen oxides that meets only the ORE B13 standard (Fig. 15).

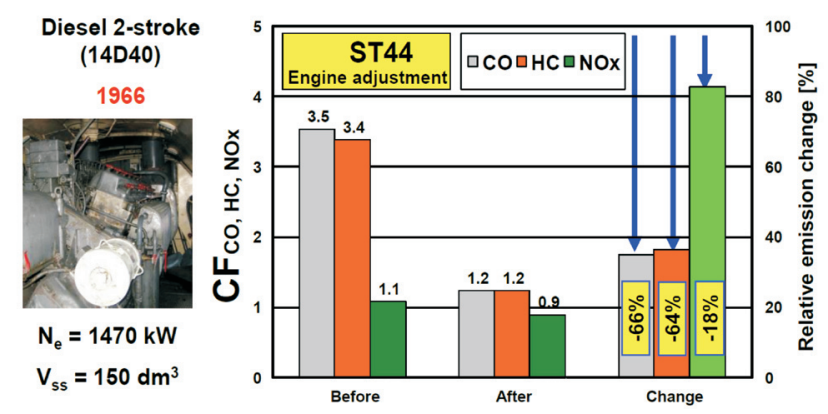

Fig. 15. ST44 cargo locomotive engine rebuild

\section{Engine replacement}

The change of the engine type results in considerable ecological benefits. In comparison to the standard 14D40 engine hourly emission of carbon monoxide was reduced by more than $80 \%$. The emission of hydrocarbons was reduced by $36 \%$. A small increase in the emission of nitrogen oxides was observed (4\%), yet the 645E3B engine has a power output more than $50 \%$ higher than its predecessor (Fig. 16).

\section{Changing rolling stock}

The above-presented range of engine adjustments, their repairs and rebuilds does not exhaust the possibilities of reducing of the exhaust emissions from rail vehicles. The diesel engines of locomotives are mainly much worn out units of high power output. These engines often do not meet the exhaust emissions requirements. They are frequently subjected to tune-ups and rebuilds in order to improve their ecological parameters. The situation with light railcars is a bit different. In this field heavy duty vehicle engines are used - high load diesel engines of maximum capacity of $25 \mathrm{dm}^{3}$.
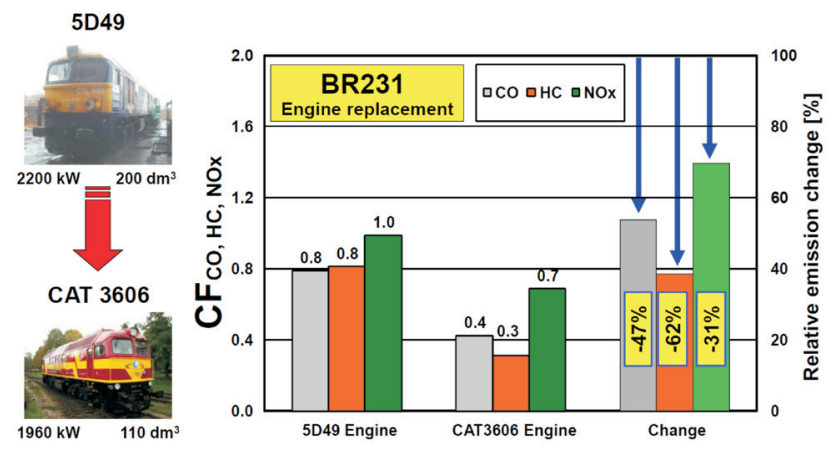

Fig. 16. Replacement of worn out locomotive engines with new designs

Because of the possibility of replacing of the deteriorated locomotives operating in passenger traffic the ecological indexes of railcars have been presented. The currently imported single, double or tri articulated railcars largely contribute to the reduction of the exhaust emissions. Following the conducted tests we can reduce the emission of carbon monoxide by over $90 \%$ when using these vehicles. Because the engines fitted in these vehicles are newer it is possible to reduce the emissions of hydrocarbons from $70 \%$ to over $90 \%$. The emission of nitrogen oxides in the worst scenario is reduced by $50 \%$. It is also possible to reduce this emission by more than $95 \%$ (Fig. 17).

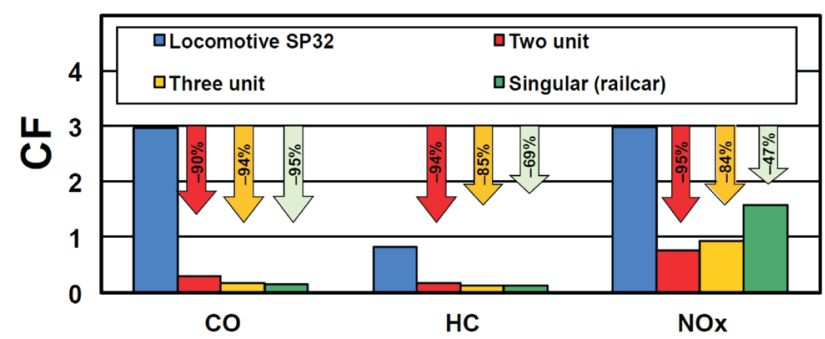

Fig. 17. The proposal of changes of the rolling stock

The SM42 locomotives mainly used in shunting could be replaced by bimodal tractors designed for shunting railroad cars (both wide and narrow gauge). The emission tests were carried out through comparing the locomotive and the bimodal tractor of the power output of approximately 100 $\mathrm{kW}$. Due to the different values of the tracting force of these vehicles the analysis of the emissions was performed with the assumption of a much-extended operating time of the bimodal tractor. As a result of such an analysis the emission of carbon monoxide was lower by more than $90 \%$. The hourly emission of hydrocarbons was also more than $90 \%$ lower. The emission of nitrogen oxides under such conditions was lower by more than $80 \%$. The PM emission was lower by $70 \%$ in its hourly emission (Fig. 18).

The presented possibilities of reduction of the exhaust emissions need indicating the ecologically prevailing direction. To this end, these proposals were juxtaposed using the multiplicity factor in the emission level as the indicator. 
A very advantageous is the proposal of using railcars. The application of these railcars results in a reduction of nitrogen oxides by almost 4 times, hydrocarbons -5 times and carbon monoxide as much as 10 times (Fig. 19). Thanks to the presented solutions it is possible to reduce the adverse impact of diesel locomotives on the environment.

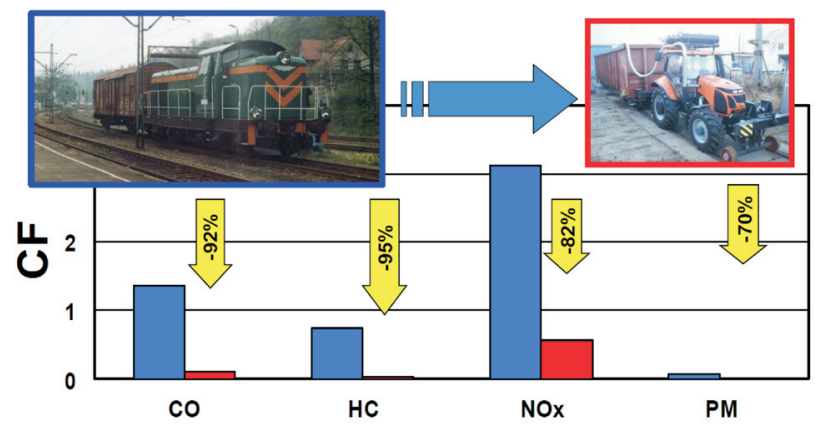

Fig. 18. Replacement of diesel locomotives with light railcars

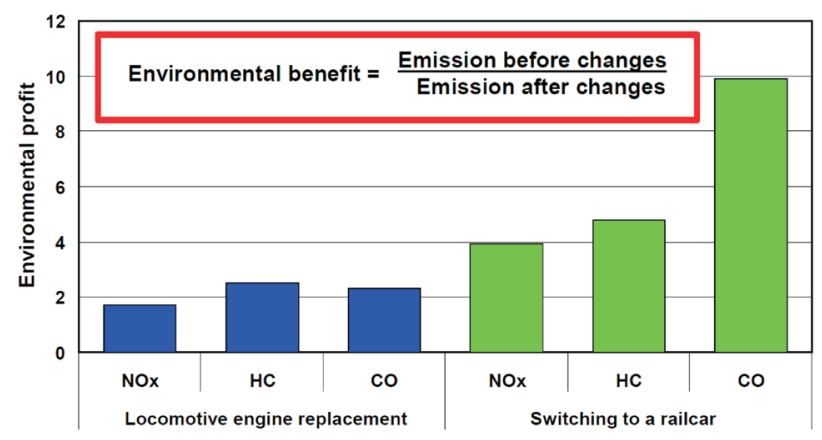

Fig. 19. Ecological benefit: the multiplicity of the ecological benefit of the most efficient solutions

The economic benefits of the application of the methods and measures reducing the negative impact of rail vehicles on the environment are:

- Reduction of fuel consumption up to $50 \%$,

- Reduction of the lubricant consumption up to $70 \%$,

- Increase of the locomotive power output $60 \%$,

- Extension of the active operation period by at least 20 years,

- Extension of the rebuild intervals,

- Reduction of the malfunction index 2.5 times,

- Self-financing of the investment in the period of approximately 10 years.

Besides, particularly advantageous are the economic effects of replacing of the diesel locomotive by bimodal vehicles (Fig. 20):

- The purchase price of the bimodal vehicle is three times lower as opposed to the cheapest shunting locomotive,

- The operating costs of operation of the tractor are six times lower as compared to the locomotive,

- Tractive properties are three times higher,

- The vehicle can be operated without additional permits on own sidetracks,

- The railway and tramway infrastructure including the onsite organization activities can be mechanized,

- Used on-road vehicles can be adapted for the purpose of rail and road vehicles,
- The vehicles can be purchased at competitive prices.

The replacement of shunting locomotives with a bimodal tractor in a double work shift system guarantees a return of the expenditure within two years.

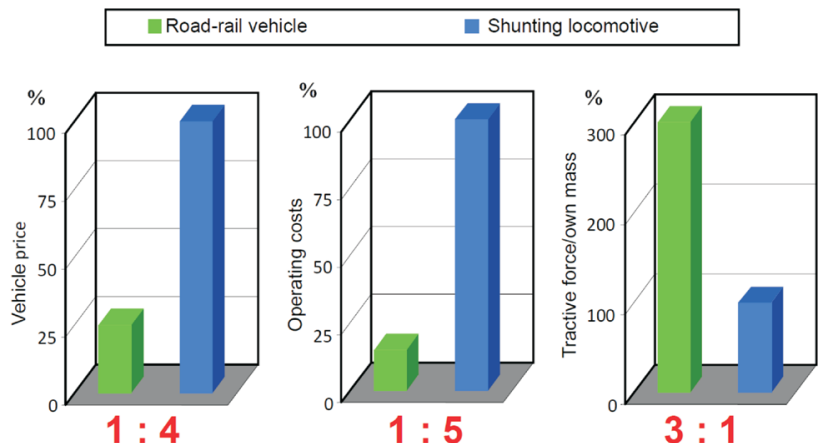

Fig. 20. Comparison of the advantages of the bimodal tractor and a diesel shunting locomotive

\section{Conclusions}

The reduction of exhaust emissions requires a continuous search for new solutions in both engine design and methods of engine testing. A factor stimulating this development is the exhaust emission legislation. The advancement of exhaust emission measurement techniques provides new possibilities of engine testing particularly under actual conditions of operation (RDE). One may suppose that this method will become prevalent and will gain in significance. The aim of the legislators and manufacturers should be the acknowledgment of the RDE measurements as one of main methods of homologation testing. Works aiming at introducing such changes should be completed as soon as possible and the enforceability of the implemented legislation should be global.

The performed investigations confirm that for NRMM engines the main problem is the emission of $\mathrm{NO}_{\mathrm{x}}$ and PM. The improvement of engines of these vehicles should be directed towards reduction of the said exhaust components. In this respect, the portfolio of possible solutions is quite large, which is confirmed by the solutions implemented on road vehicles. Such solutions can then successfully be transferred to NRMM vehicles.

The here presented possibilities of changes to the traditional railway vehicles i.e. modernization, replacements of the old diesel engines with more technologically advanced units and the use of light railcars and special purpose vehicles (bimodal tractors) required indicating the ecologically prevailing trends. The knowledge of how the railway vehicles affect the environment required an actual evaluation of the real operating conditions and determining of the exhaust emissions under these conditions. It is possible only having considered their specific operation. This task is particularly complex as diesel locomotives do not have identical load histograms - variable operating conditions generated variable values of the exhaust emissions. In order to obtain the full ecological 'picture' of the condition of the diesel locomotive units a mobile testing laboratory was built for the exhaust emission testing.

The most efficient method of limiting of the negative impact of rail vehicles on natural environment is to replace 
the locomotive engine or replace the locomotive itself with light railcars. Other methods of reducing of the exhaust emissions such as engine tune-up or engine rebuilds do not bring expected results.

According to the newly developed test the exhaust emissions from locomotives used for: passenger trains - are lower by $20-40 \%$ for all the exhaust components, shunting - are lower by approximately $50 \%$, cargo trains - have no significant differences.

\section{Bibliography}

[1] Bitter, M., Mailänder, E., Palumbo, C., Klink, G. Commercial vehicle market trends. 7th AVL International Commercial Powertrain Conference, Graz 22-23.05.2013.

[2] Global Insight, IHS, ATKearney 2012.

[3] Global Insight, Off-Highway Research, ATKearney 2012.

[4] Friedrich, A. Emission legislation for off-highway application in Germany. International CTI Forum "Emission Reduction Systems for Off-highway Applications", Stuttgart 2008.

[5] IARC: Diesel Engine Exhaust Carcinogenic. Press Release No. 213, 12.06.2012.

[6] Lijewski, P. Studium emisji związków toksycznych spalin z silników o zastosowaniach pozadrogowych. Wydawnictwo Politechniki Poznańskiej, Rozprawy nr 516, Poznań 2013.

[7] Marciniak, Z., Pielecha, I., Pielecha, J., Stawecki, W. Ekologiczne aspekty spalinowych pojazdów szynowych eksploatowanych na krajowych liniach kolejowych. Logistyka 2010, 4.

[8] Marciniak, Z., Pielecha, I., Pielecha, J., Stawecki, W. Problemy emisji spalin ze specjalnych pojazdów szynowych. Pojazdy Szynowe 2011, 2, 25-29.

[9] Marciniak, Z., Stawecki, W., Merkisz, J., Pielecha, I., Pielecha, J. Możliwości modyfikacji taboru spalinowego w celu zmniejszenia jego oddziaływania na środowisko naturalne, Technika Transportu Szynowego 2011, 3(18), 43-48.

[10] Markowska, K. The market for rail freight services - certain selected aspects. Journal of KONES Powertrain and Transport 2015, 3(22), 149-153.

[11] Merkisz, J., Fuć, P., Lijewski, P. Fizykochemiczne aspekty budowy i eksploatacji filtrów cząstek stałych. Wydawnictwo Politechniki Poznańskiej, Poznań 2016.

[12] Merkisz, J., Lijewski, P., Fuć, P., Siedlecki, M., Weymann, $\mathrm{S}$. The use of the PEMS equipment for the assessment of farm fieldwork energy consumption. Applied Engineering in Agriculture 2015, 31(6), 875-879.

[13] Merkisz, J., Pielecha, J., Radzimirski, S. European Union Emission Standard Euro V and Euro VI Technology. Chemical Industry Press, Beijing, China, 2016, 1, 160.

[14] Moser, F.X. Future powertrains - increasing complexity or more opportunities for synergies? 6th AVL International Commercial Powertrain Conference, Proceedings, Graz 2526.05.2011.

[15] Neilssen, D. EU Transport GHG: routes to 2050? Economic Instruments and Emission Trading Non-Road Transport Modes. Technical Focus Group Meeting 7, Brussels 2.10.2009.

Prof. Jerzy Merkisz, DSc., DEng. - Professor in the Faculty of Machines and Transport at Poznan University of Technology.

e-mail: jerzy.merkisz@put.poznan.pl
The replacement of diesel locomotives with light railcars results in a significant reduction of the exhaust emissions: carbon monoxide by $90-95 \%$, hydrocarbons by $69-94 \%$, nitrogen oxides by $47-95 \%$.

The research was funded by project co-financed by the European Regional Development Fund in the Regional Program - Wielkopolskie 2020 (contract No. RPWP.01.02.00-30-0069/16)

[16] Phillips, D.C.A. Global trends in the construction equipment industry. 6th AVL International Commercial Powertrain Conference, Graz 25-26.05.2011.

[17] Pielecha, I., Pielecha, J. Tendencje w przepisach dotyczących emisji związków toksycznych przez silniki spalinowe pojazdów szynowych. Pojazdy Szynowe 2005, 1, 52-59.

[18] PN-EN ISO 8178-4, Silniki spalinowe tłokowe. Pomiar emisji spalin. Cykle badawcze silników o różnym zastosowaniu. Wyd. 1999.

[19] Schneider, K., Länge, W., Ellensohn, R. Liebherr Pactronic - hybrid power booster: energy recovery and increased performance with hybrid drive system. 7th AVL International Commercial Powertrain Conference, Graz 22-23.05.2013.

[20] Sobotzik, J. Electric drives in mobile agricultural machinery - products and potentials. 7th AVL International Commercial Powertrain Conference, Graz 22-23.05.2013.

[21] Stawecki, W., Marciniak, Z., Pielecha, I., Pielecha, J. Ekologiczne aspekty modernizacji lokomotyw spalinowych w Polsce. Prace Naukowe Politechniki Warszawskiej, Transport: Środki i infrastruktura transportu, z. 98, Oficyna Wydawnicza Politechniki Warszawskiej, Warszawa 2013, 615-624.

[22] Stawecki, W., Marciniak, Z., Pielecha, I., Pielecha, J. Problems of exhaust gas emission of modernized diesel locomotives operating in Poland. Combustion Engines 2014, 1(156), 4858.

[23] The Office of Rail, An Evaluation of the Railway Transport Market and the State of Railway Traffic Safety in 2011. TOR Publishing House, The Division of Analysis of The Department of Railway Market Regulation of The Railway Transport Office, 2012.

[24] The White Book of 2013, Time for action - a map of the problems with Polish railways, the initiative of the Railway Business Forum. Second Edition of The White Book 2010, revised and updated, Warsaw-Krakow 2013.

[25] Worldwide Emissions Standards, heavy duty and off-highway vehicles. Delphi Innovation for the Real World, 2012/2013.

Piotr Lijewski, DEng. - doctor in the Faculty of Machines and Transport at Poznan University of Technology.

e-mail:piotr.lijewski@put.poznan.pl

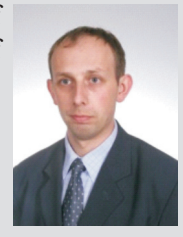

Jacek Pielecha, DSc., DEng. - Professor in the Faculty of Machines and Transport at Poznan University of Technology.

e-mail: jacek.pielecha@put.poznan.pl

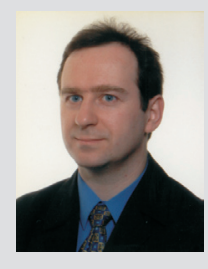

